\title{
Mitoxantrone resistance in a small cell lung cancer cell line is associated with ABCA2 upregulation
}

\author{
R Boonstra', H Timmer-Bosscha ${ }^{2}$, J van Echten-Arends ${ }^{3}$, DM van der Kolk ${ }^{2}$, A van den Berg', B de Jong ${ }^{3}$, \\ KD Tew ${ }^{4}, S_{\text {Poppema' }}$ and EGE de Vries ${ }^{*, 2}$
}

'Department of Pathology and Laboratory Medicine, University Hospital Groningen, The Netherlands; ${ }^{2}$ Department of Medical Oncology, University Hospital Groningen, The Netherlands; ${ }^{3}$ Department of Genetics, University Hospital Groningen, The Netherlands; ${ }^{4}$ Department of Pharmacology,

Fox Chase Cancer Center, Philidelphia, Pennsylvania 19111, USA

The aim of this study was to find factors that could explain the accumulation difference of mitoxantrone in the BCRPI-negative GLC4-MITO cell line compared to GLC4. Comparative genomic hybridisation (CGH) was applied to determine chromosomal differences between GLC4 and GLC4-MITO. Comparative genomic hybridisation analysis revealed gain of 2q, 6p, 9q, I3q, I4q, I5q, $19 q$ and $X p$ and loss of I p, 2q, 3p, 3q, 4q, 6q, 8q, II p, I6p, I7q, I8p, 20p and Xq. In the over-represented chromosomal areas, seven transporter genes were identified: ABCB6, ABCB2 (TAPI), ABCB3 (TAP2), ABCFI (ABC50), ABCCI0 (MRP7), ABCA2 (ABC2) and $A B C C 4$ (MRP4). No RNA or protein upregulation was observed for $A B C B 6, A B C F I, A B C C I 0, A B C C 4, A B C B 2$ and $A B C B 3$, but an increased expression was detected for ABCA2 mRNA in GLC4-MITO. ABCA2 is known to be involved in resistance to estramustine. In the MTT assay, GLC4-MITO was two-fold resistant to estramustine compared to GLC4. Coincubation with estramustine and mitoxantrone increased mitoxantrone accumulation in GLC4-MITO, while this was not affected in GLC4. This suggests that estramustine is able to block mitoxantrone efflux in GLC4-MITO cells. These data reveal that cellular reduction of mitoxantrone in a mitoxantrone-resistant cell line is associated with overexpression of ABCA2.

British Journal of Cancer (2004) 90, 24II-24I7. doi:I0.1038/sj.bjc.6601863 www.bjcancer.com

Published online 18 May 2004

(c) 2004 Cancer Research UK

Keywords: $\mathrm{CGH}$; multidrug resistance; mitoxantrone; GLC4-MITO; ABCA2

The treatment of patients with anticancer agents is still seriously hampered by the occurrence of resistance against standard anticancer drugs and crossresistance to many other cytotoxic agents. The ATP-binding cassette transporter (ABC) superfamily has been implicated as a major contributor to the multidrugresistance phenotype (Klein et al, 1999). The most studied members are the P-glycoprotein (P-gp) encoded by the MDR1 gene (Ambudkar et al, 1999) and the MDR-related protein (MRP) family of the ABC protein transporters, especially the MRP1 gene (Borst et al, 1999). Currently, 48 human ABC transporters are known (Müller M (2001). Transporters in the liver and ATPbinding Casette (ABC)-Proteins October 2002 Internet communication, http://nutrigene.4t.com/humanabc.htm). In addition, it has become clear that often more than one mechanism is involved in multidrug-resistance of tumor cells.

Resistance to the anticancer drug mitoxantrone has been associated with several mechanisms including drug accumulation defects and reduction in its target proteins topoisomerase II $\alpha$ and $\beta$ (Withoff et al, 1996). Recently, overexpression of the breast cancer-resistance half-transporter protein (BCRP1) was found to be responsible for the occurrence of mitoxantrone resistance in a number of cell lines (Doyle et al, 1998; Miyake et al, 1999; Ross

*Correspondence: Dr EGE de Vries, Department of Medical Oncology, University Hospital Groningen, PO Box 30.00 I, 9700 RB Groningen, The Netherlands; E-mail: e.g.e.de.vries@int.azg.nl

Received 5 December 2003; revised 16 March 2004; accepted 18 March 2004; published online 18 May 2004 et al, 1999; Litman et al, 2000). However, not all mitoxantroneresistant cell lines express BCRP1 (Hazlehurst et al, 1999; Nielsen et al, 2000). The efflux pump responsible for the mitoxantrone resistance in these cell lines is as yet unknown. The mitoxantroneresistant GLC4 subline GLC4-MITO exhibits a reduced mitoxantrone accumulation (Withoff et al, 1996). Scheffer et al (2000) had already shown that there was no BCRP1 protein expression in GLC4-MITO using BXP-34 antibody. This suggests that a different efflux pump may be involved in mitoxantrone resistance in GLC4-MITO.

We used comparative genomic hybridisation (CGH) to determine chromosomal differences between the human small cell lung cancer cell line (SCLC) GLC4 and its mitoxantrone-resistant subline. Comparison of the cell lines showed gains of specific chromosomal regions. Screening of several databases revealed seven known efflux pumps located in the amplified regions. A possible involvement of these pumps was analysed by reverse transcriptase-polymerase chain reaction (RT-PCR) for mRNA expression, cytotoxicity with the microculture tetrazolium assay (MTA), drug accumulation by flow cytometry analysis and immunocytochemistry for protein expression.

\section{MATERIAL AND METHOD}

\section{Cell lines}

For this study, we used two cell lines: GLC4, a drug-sensitive human SCLC cell line and GLC4-MITO, a GLC4 subline with an in 
vitro induced mitoxantrone resistance (Zijlstra et al, 1986; Withoff et al, 1996). GLC4-MITO was previously shown to exhibit a $60 \%$ reduced topoisomerase II $\alpha$ compared to GLC4 and no topoisomerase II $\beta$ RNA expression at all. In addition, a decreased mitoxantrone accumulation was found. There was a 3.6-fold crossresistance to doxorubicin without reduction in doxorubicin accumulation (Withoff et al, 1996). Earlier studies detected no overexpression or activation of P-gp, MRP1 (multidrug-resistant protein) and LRP (lung-resistance protein) in the GLC4-MITO cell line (Withoff et al, 1996). Both cell lines were cultured in RPMI 1640 supplemented with $10 \%$ heat-inactivated fetal calf serum, $\left(37^{\circ} \mathrm{C}, 5 \% \mathrm{CO}_{2}\right)$. GLC4-MITO was incubated twice monthly with $285 \mathrm{nM}$ mitoxantrone to maintain the mitoxantrone resistance. Before performing the experiments described below, cells were cultured drug free for 14 days. Routinely mitoxantrone sensitivity was checked by MTA every 3 months. A mean mitoxantroneresistance factor of 33-fold was established. For the RT-PCR experiments, we used MCF7, a human breast carcinoma cell line and MCF7-MX, its 1395-fold mitoxantrone-resistant subline with increased BCRP1 mRNA expression compared to MCF7 (Ross et al, 1999; Volk et al, 2000) as controls. For the MTA experiments with estramustine, we included GLC4-ADR, a 150-fold doxorubicinresistant GLC4 subline with increased MRP1 and LRP expression but no reduced mitoxantrone accumulation (Zijlstra et al, 1987) as a control.

\section{Cytogenetics}

The cell cultures were harvested and chromosome preparations were made using standard cytogenetic techniques. The chromosomes were G-banded using $0.1 \%$ pancreatin (Sigma, Zwijndrecht, the Netherlands) and $10 \%$ Giemsa. A total of 10 metaphases from the GLC4 and the GLC4-MITO cell line were analysed. Karyotypes were described according to the ISCN (1995). chromosomal pattern of GLC4-MITO was compared with that of GLC4.

\section{Comparative genomic hybridisation}

Cells of subconfluent cultures were harvested and genomic DNA was extracted according to standard methods. Comparative genomic hybridisation was performed as described by Kallioniemi et al (1992) with some adjustments. Approximately $1 \mu \mathrm{g}$ of test DNA and $1 \mu \mathrm{g}$ of reference DNA were labelled by nick translation with either Biotin-16-dUTP or digoxigenin11-dUTP (Roche Molecular Biochemicals, Almere, Netherlands). Aliquots of $400 \mathrm{ng}$ labelled test DNA and control DNA were ethanol precipitated with $50 \mu \mathrm{g}$ unlabelled human Cot1 DNA (Life Technologies, Breda, the Netherlands) and $10 \mu \mathrm{g}$ of salmon sperm DNA (Sigma, Zwijndrecht, the Netherlands). The DNA solution was dissolved in $15 \mu \mathrm{l}$ hybridisation mixture $(50 \%$ deionized formamide, $2 \times$ SSC, $10 \%$ dextran sulphate $\mathrm{pH} 7.0$ ) and applied to a normal male metaphase slide (Vysis, Downers Grove, IL, USA). The slide with the DNA hybridisation solution was denatured at $74^{\circ} \mathrm{C}$ for $3 \mathrm{~min}$ and hybridized at $37^{\circ} \mathrm{C}$ for $72 \mathrm{~h}$. Posthybridisation washes with $4 \times$ saline-sodium citrate (SSC), $3 \times 0.1 \times$ SSC at $60^{\circ} \mathrm{C}$ were performed before immunochemical detection. Immunochemical detection was performed using streptavidin-FITC (Roche Molecular Biochemicals) and antiDIG-TRITC (Roche Molecular Biochemicals, Almere, Netherlands) in $4 \times$ SSC, Tween-20 and $1 \%$ fat-free powder milk during $1 \mathrm{~h}$ to detect the biotin-labelled tumour DNA and digoxigenin-labelled normal DNA. The slides were mounted with antifading solution containing 4,6-diamidino-2-phenylindole (DAPI), used as a counter stain (Vectashield, Vector laboratories, Burlingame, CA, USA).

The grey-scale images of the three different fluorochromes were captured using a Leica DMRA fluorescence microscope equipped with DAPI, FITC and TRITC filters (Chroma, Brattleboro, VT,
USA), CCD camera (Cohu 4912 CCD camera, San Diego, CA, USA) and the image-capturing program QFISH (Leica, Cambridge, UK). The three captured images were combined and pseudocolor was applied matching the original colours of the fluorochromes. The ratio between the FITC (tumour cell line) and TRITC (normal) fluorescence was calculated with use of the QCGH software program (Leica, Cambridge). For each case, the mean of the individual ratio profiles of 8-10 metaphase spreads was calculated. The GLC4 and the GLC4-MITO cell line were compared with normal DNA. In addition, we directly compared GLC4-MITO with its parent line GLC4.

\section{RNA extraction and RT - PCR}

Total cellular RNA was isolated from $5 \times 10^{6}$ cells using $1 \mathrm{ml}$ of Trizol reagent (Life Technologies, Breda, the Netherlands). RNA was extracted, precipitated and washed according to the manufacturer's protocol. RNA $(2 \mu \mathrm{g})$ was reverse transcribed in $20 \mu \mathrm{l}$ of reverse transcriptase (RT) buffer (Life Technologies), supplemented with $1.8 \mathrm{~mm}$ dTTP (Promega Corp., Madison, WI, USA), $10 \mathrm{U}$ of Moloney murine leukemia virus RT (AmershamPharmacia, Woerden, The Netherlands), $4.8 \mathrm{U}$ RNAguard (Amersham-Pharmacia, Woerden, The Netherlands), $0.2 \mu \mathrm{g} p \mathrm{pd}(\mathrm{N})_{6}$ random primers (Amersham-Pharmacia,) and $3 \mathrm{~mm}$ dithiothreitol (Life Technologies). The reaction conditions were $65^{\circ} \mathrm{C}$ for $10 \mathrm{~min}$ and $37^{\circ} \mathrm{C}$ for $60 \mathrm{~min}$. After this incubation, $30 \mu \mathrm{l} \mathrm{H}_{2} \mathrm{O}$ was added up to a final volume of $50 \mu \mathrm{l}$ cDNA. Polymerase chain reaction analysis was performed in $25 \mu \mathrm{l} \mathrm{PCR}$ buffer containing $2 \mu \mathrm{l}$ of cDNA using the primer pairs and conditions as described in Table 1.

The PCR reaction product bands were visualised by ethidium bromide staining. Densitometric scanning was performed with an Image Master VDS (Pharmacia, Woerden, The Netherlands), and optical density (OD) was expressed as $\mathrm{OD} \times \mathrm{mm}^{2}$ using the program Diversity One 1D (PDI, New York, NY, USA).

\section{Immunocytochemistry for ABCB2 (TAP1), ABCB3 (TAP2) proteins}

Cytospin slides were prepared from cultured GLC4 and GLC4MITO cells. The cytospins were fixed in acetone for $10 \mathrm{~min}$, transferred to ice-cold methanol for $10 \mathrm{~min}$ and washed with phosphate-buffered saline (PBS), $\mathrm{pH}$ 7.4. The cytospins were incubated for $1 \mathrm{~h}$ at room temperature with the primary antibody ABCB2 (TAP1), ABCB3 (TAP2) (antibodies kindly provided by $\mathrm{Dr}$ J Neefjes, Dutch Cancer Institute, the Netherlands) diluted in $1 \%$ bovine serum albumin in PBS. Endogenous peroxidase was blocked with $0.3 \% \mathrm{H}_{2} \mathrm{O}_{2}$ for $30 \mathrm{~min}$. For $\mathrm{ABCB} 3$ and $\mathrm{ABCB} 2$ antibodies, the second step was performed with peroxidaseconjugated rabbit anti-mouse antibody (Dakopatts, Glosstrup, Denmark) supplemented with $1 \%$ human serum, followed by incubation with goat anti-rabbit antibody (Dakopatts). The visualisation was performed in a freshly prepared solution of 3-amino-9-ethylcarbazol (AEC), containing $0.03 \% \quad \mathrm{H}_{2} \mathrm{O}_{2}$ for $10 \mathrm{~min}$. Counterstaining was performed using Mayer's haematoxylin. Control slides, in which PBS replaced the first antibody, were consistently negative.

\section{Cytotoxicity assay}

Cytotoxicity of estramustine was determined using MTA as described before (Timmer-Bosscha et al, 1989). Before the assays were performed, cell growth studies were carried out, and the linear relationship of cell number to formazan crystal formation was checked. Each cell line was seeded at optimum density in order to test survival after at least two to three cell divisions had taken place in the control cells. For GLC4, $3 \times 10^{4}$ cells ml ${ }^{-1}$ and for GLC4-ADR and GLC4-MITO, $7.510^{4}$ cells $\mathrm{ml}^{-1}$ were incubated 
Table I Primer sequences and PCR conditions for the ATP-binding cassette transporter (ABC) genes that were located in the amplified chromosomal regions, BCRPI, MRPI, MRP2, MRP5 and the control genes hypoxanthine phosphoribosyltransferase (HPRT) and $\beta-2$ microglobulin, used for DNA amplification in the RT-PCR

\begin{tabular}{|c|c|c|c|c|c|}
\hline Gene & Sense primer $\left(5^{\prime} \rightarrow 3^{\prime}\right)$ & Antisense primer $\left(3^{\prime} \rightarrow 5^{\prime}\right)$ & Temperature $\left({ }^{\circ} \mathrm{C}\right)$ & $\begin{array}{l}\text { Cycles } \\
(n)\end{array}$ & $\begin{array}{l}\text { Product size } \\
\text { (base pairs) }\end{array}$ \\
\hline ABCB6 & GGG CCG TAT TGA GTT TGA GA & ATG TCC TGC CCA TCT ATT CG & $95,55,72^{\mathrm{a}}$ & 26 & 201 \\
\hline ABCCIO (MRP7) & CTC CCA CTG GAT CTC TCA GC & TCG CAT ACA CGG TGA GGT AG & $95,57,72^{\mathrm{a}}$ & 30 & 200 \\
\hline$A B C A 2(A B C 2)$ & GAG ATC CGC AGA GAG ATG GA & CTT CAG GAT GAG GTC CCA GA & $95,57,72^{\mathrm{a}}$ & 30 & 207 \\
\hline ABCC4 (MRP4) & AAT ACC CTT GGT TCC CCT TGG & ATC CTG GTG TGC ATC AAA CA & $95,55,72^{\mathrm{a}}$ & 32 & 202 \\
\hline ABCG2 (BCRPI) & CAG AGA TCA TAG AGC CTT CC & ACA CTC TGT AGT ATC CTC TG & $95,55,72^{\mathrm{a}}$ & 32 & 453 \\
\hline ABCC5 (MRP5) & GGA TAA CTT CTC AGT GGG & GGA ATG GCA ATG CTC TAA AG & $95,55,72^{\mathrm{a}}$ & 29 & 380 \\
\hline HPRT & CGT GGG GTC CTT TTC ACC AGC AAG & AAT TAT GGA CAG GAC TGA ACG TC & $95,55,72^{\mathrm{a}}$ & 27 & 380 \\
\hline$\beta-2$ microglobulin & CCA GCA GAG AAT GGA AAG TC & GAT GCT GCT TAC ATG TCT CG & $95,55,72^{\mathrm{a}}$ & 20 & 268 \\
\hline
\end{tabular}

${ }^{\mathrm{a}}$ For denaturation $\left(30^{\prime \prime}\right)$, annealing $\left(30^{\prime \prime}\right)$, extension $\left(30^{\prime \prime}\right)$.

continuously for 4 days with estramustine concentrations ranging from 1 to $100 \mu \mathrm{m}$. Controls consisted of media without cells (background extinction) and cells incubated in microculture wells with medium without the drug. The surviving fraction was calculated by the ratio of mean extinction of test sample to mean extinction of untreated control sample. Inhibition concentration (IC) $50, \mathrm{IC}_{70}$ and $\mathrm{IC}_{90}$ were defined as the doses of estramustine inducing 50,70, and $90 \%$ reduction in cell survival, respectively. Experiments were performed four times each in quadruplicate.

\section{Flow cytometric detection of mitoxantrone accumulation}

The ability of tumour cell lines GCL4 and GLC4-MITO to extrude mitoxantrone in the absence or presence of the ABCA2 modulator estramustine, the P-gp inhibitor PSC833 (provided by Novartis Pharma Inc., Basel Switzerland), the BCRP1 inhibitor fumitremorgin C (FTC) (kindly provided by SE Bates) and the leukotriene D4 receptor antagonist and MRP inhibitor MK-571 (provided by Sanvertech, Heerhugowaard, The Netherlands) was measured in a fluorescence-activated cell sorting (FACS) assay (Van der Kolk et al, 2002). Cells $\left(1 \times 10^{6}\right)$ were preincubated with these inhibitors for $30 \mathrm{~min}$ at $37^{\circ} \mathrm{C}, 5 \% \mathrm{CO}_{2}$, in the following combinations: RPMI 1640 medium alone $(0.5 \mathrm{ml})$, RPMI 1640 medium plus $10 \mu \mathrm{M}$ FTC, or plus $2 \mu \mathrm{g} \mathrm{ml}^{-1}$ PSC833 or plus $20 \mu \mathrm{M} \mathrm{MK}-571$. Thereafter, $3 \mu \mathrm{M}$ mitoxantrone was added and the cells were incubated for $60 \mathrm{~min}$ at $37^{\circ} \mathrm{C}, 5 \% \mathrm{CO}_{2}$

Cells $\left(1 \times 10^{6}\right)$ were preincubated with and without 10 or $25 \mu \mathrm{M}$ estramustine (modulator of ABCA2), $3 \mu \mathrm{M}$ mitoxantrone was added and the cells were incubated for $60 \mathrm{~min}$ at $37^{\circ} \mathrm{C}, 5 \% \mathrm{CO}_{2}$. Cells were washed with ice-cold RPMI 1640 medium. Fluorescence of mitoxantrone was analysed with a FACScalibur flow cytometer (Becton Dickson Medical Systems, Sharon, MA, USA), equipped with an argon laser. The viable cell population was gated by forward and sideways scatter characteristics. The mitoxantrone fluorescence of 10000 -gated events was logarithmically measured at a laser excitation wavelength of $635 \mathrm{~nm}$ through a $670 \mathrm{~nm}$ bandpass filter. Mitoxantrone accumulation was expressed as median fluorescence intensity (MFI). The effect of the various modulators was expressed as a shift of MFI of the mitoxantrone accumulation (Van der Kolk et al, 2002). Measurements were performed on duplicate samples and experiments were performed in triplicate.

\section{Statistics}

For the statistical analysis of the data retrieved in the mitoxantrone accumulation and cytoxicity experiments, we used the paired or unpaired Student's $t$-test.

\section{RESULTS}

Cytogenetics revealed a complex karyotype with marker chromosomes in both GLC4 and GLC4-MITO (data not shown). Comparison of the $\mathrm{CGH}$ results with cytogenetics showed that numerical differences detected with CGH were also observed in the karyotypes of GLC4 and GLC4-MITO.

Comparative genomic hybridisation was used to compare the mitoxantrone-resistant cell line with its sensitive parental line GLC4. In addition, we also compared both cell lines with a normal DNA sample (genomic DNA isolated from peripheral blood lymphocytes from a healthy person). Results of all CGH experiments are shown in Figure 1. The CGH results of GLC4MITO vs GLC4 are summarized in Table 2. Loss (17x) of chromosomal material was more frequent than gain $(8 \mathrm{x})$ in GLC4-MITO compared to GLC4. Relative to GLC4 no high level amplifications could be detected in GLC4-MITO using CGH. We detected loss of $3 p$ (containing the topoisomerase II $\beta$ gene) and $17 \mathrm{q}$ (containing the topoisomerase II $\alpha$ gene) in GLC4-MITO providing a plausible explanation for the previously identified reduction of topoisomerase activity (Withoff et al, 1996).

The genomic areas enriched in GCL4-MITO as compared with GLC4 were screened in a database for the presence of known drug resistance-related transporter genes (Müller M (2001) Transporters in the Liver and ATPbinding Casette (ABC)-Proteins October 2002. Internet communication, http://nutrigene.4t.com/humanabc.htm). We identified seven known transporter genes: ABCB6 (ABCB6) (Allikmets et al, 1996), ABCB2 (TAP1), ABCB3 (TAP2) (Bahram et al, 1991), ABCC10 (MRP7) (Hopper et al, 2001), ABCF1 (ABC50) (Richard et al, 1998), ABCA2 (ABC2) (Vulevic et al, 2001) and ABCC4 (MRP4) (Kool et al, 1997) (see Table 3).

These transporter genes located at $2 \mathrm{q}, 6 \mathrm{p}, 9 \mathrm{q}$ and $13 \mathrm{q}$, respectively, were analysed for overexpression at the RNA and/or protein level. $\mathrm{ABCB} 2$ and $\mathrm{ABCB} 3$ protein expression was screened by immunocytochemistry. Staining with the anti-ABCB2 antibody revealed a comparable, weakly positive, cytoplasmatic staining in GLC4 and GLC4-MITO. With the anti-ABCB3 antibody, a moderate to strong cytoplasmatic staining pattern was observed with no differences between both cell lines. Reverse transcriptasepolymerase chain reactions were performed for the other four transporter genes, for the BCRP1 gene (known to be involved in mitoxantrone resistance) and for MRP1, MRP2 and MRP5 as controls. Densitometric scanning of the PCR reaction product bands revealed similar expression levels for ABCB6, ABCF1, ABCC10, ABCC4, MRP1 and MRP5 in the parental cell line GLC4 as compared with resistant line GLC4-MITO. MRP2 was slightly higher in GLC4-MITO, but FACS results showed no difference in 
A GLC4-MITO vs GLC4
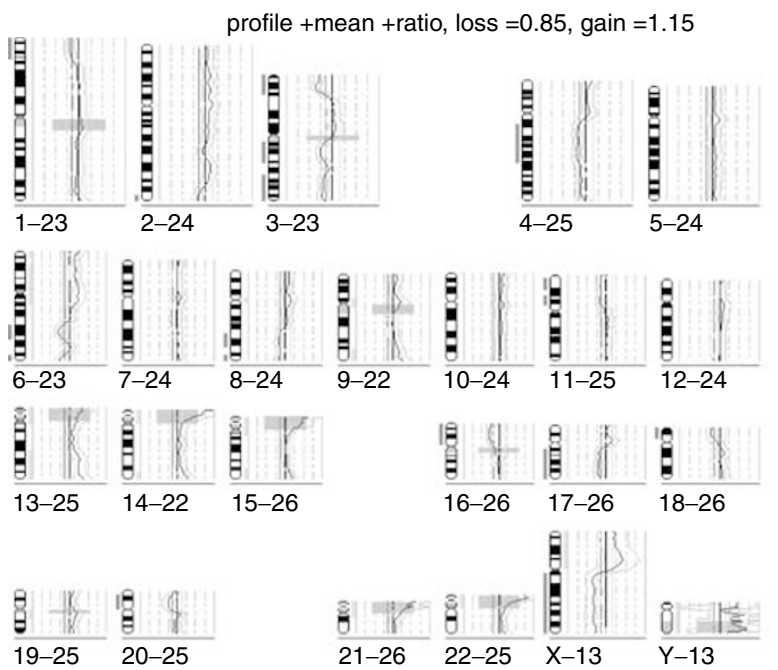

\section{GLC4-MITO vs GLC4 normal DNA}

profile +mean +ratio, loss $=0.85$, gain $=1.15$
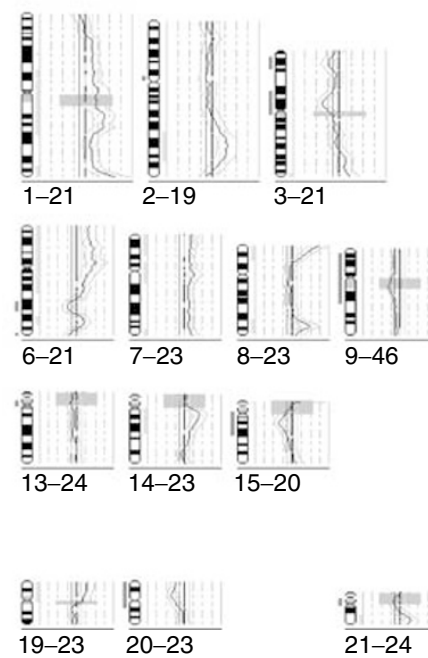
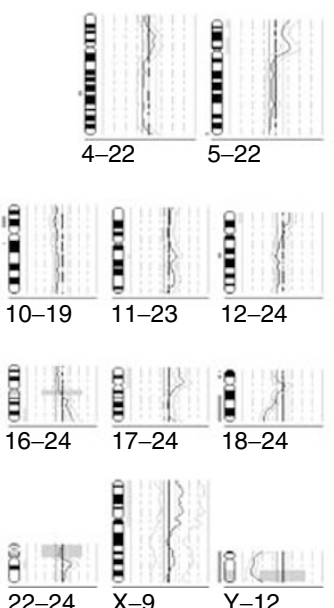

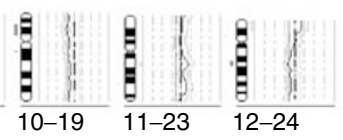

B GLC4 vs normal DNA

profile + mean + ratio, loss $=0.85$, gain $=1.15$
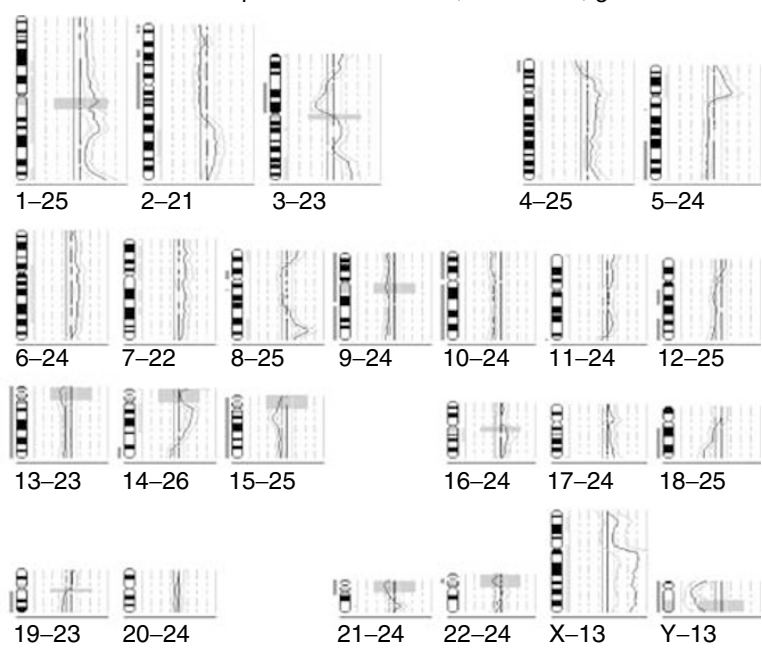

D Explanation CGH profile

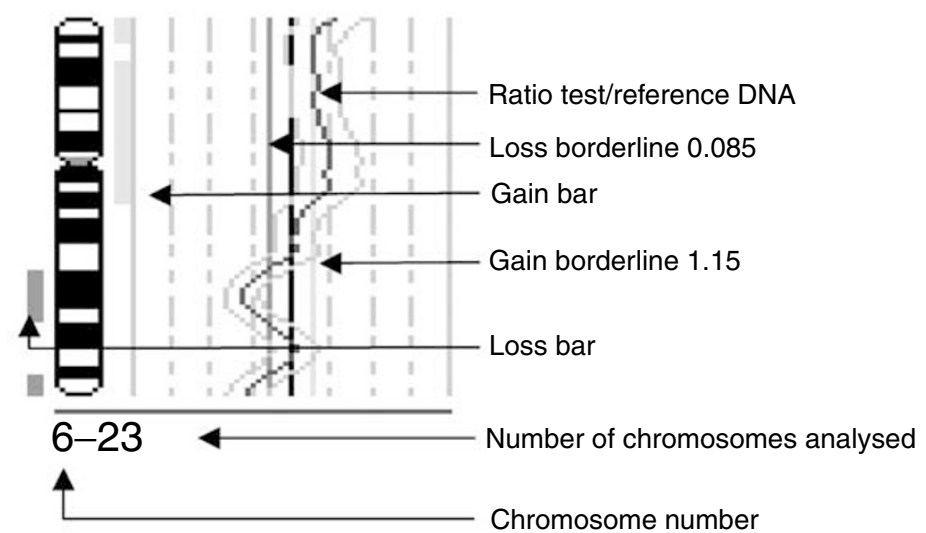

Table 2 Copy number changes detected by CGH in GLC4-MITO vs GLC4

Figure I Comparative genomic hybridisation profiles of GLC4-MITO vs GLC4 and normal control DNA. (A) CGH profile of GLC4-MITO vs GLC4 (blue line) (B) CGH profile of GLC4 vs normal male DNA. (C) CGH profile of GLC4-MITO vs normal male DNA. (D) Explanation of schematic representation of a CGH profile gain > 1.I5(green bar) loss <0.85 (red bar).

\section{Gain}

rev ish enh(2q34 6p25q14 9q34 13q2।q34 14q32 15q24q26 19q10q13.1 Xp)

Loss

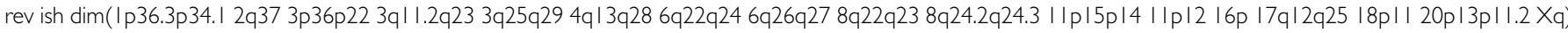

$\mathrm{CGH}=$ comparative genomic hybridisation.

the effect of MRP inhibitor MK-571 on GLC4 and GLC4-MITO. Reverse transcriptase - polymerase chain reaction revealed a lower mRNA level of BCRP1 in GLC4-MITO compared with GLC4 cell line(see Figure 2). However, the ABCA2 transporter showed a stronger signal in GLC4-MITO as compared to GLC4 indicating an increased expression level. Densitometric scanning of the PCR reaction product bands revealed a two-fold higher signal of GLC4-MITO (GLC4-MITO/HPRT: $(n=3$, ratio $=2.84 \pm 0.17)$ compared to the GLC4 (GLC4/HPRT: $(n=3$, ratio $=1.44 \pm 0.04)$ signal using the housekeeping gene HPRT as a loading control (triplicate experiments).

ABCA2 was shown by Laing et al (1998) to confer resistance to estramustine in an ovarian cancer cell line. In order to demonstrate functionality of ABCA2 in GLC4-MITO, a cytotoxicity assay with estramustine in GLC4-MITO, GLC4-ADR and GLC4 was performed. Figure 3 shows the result of the cytotoxity assay. A 1.5and 2.0-fold higher drug concentration was needed to obtain the $\mathrm{IC}_{70}$ and $\mathrm{IC}_{90}$, respectively, in GLC4-MITO compared to GLC4. The 
GLC4-ADR cell line with increased MRP1 and LRP expression (but no reduced mitoxantrone accumulation) was more sensitive to estramustine than the GLC4 and GLC4-MITO cell line. A 2.5-fold lower drug concentration was needed to obtain the $\mathrm{IC}_{90}$ compared to GLC4 (see Figure 3).

The ability of tumour cell lines GLC4 and GLC4-MITO to extrude mitoxantrone, and the effect of estramustine on mitoxantrone accumulation were measured with a FACS assay. The mitoxantrone accumulation after exposure to $3 \mu \mathrm{M}$ mitoxantrone was $25 \%$ reduced in GLC4-MITO (76 $\pm 11 \mathrm{MFI}, P=0.03)$ compared to GLC4 (set as 100) (see Figure 4). When 10 and $25 \mu \mathrm{M}$ estramustine were added during incubation with mitoxantrone, the mitoxantrone accumulation in GLC4-MITO increased to $85 \pm 10$ MFI $(n=3, P=0.004)$ with $10 \mu \mathrm{M}$ estramustine and to $106 \pm 15$ MFI $(n=3, P=0.03)$ with $25 \mu \mathrm{M}$ estramustine. However, mitoxantrone accumulation was not effected in GLC4, 101 \pm 5 MFI $(n=3, P=0.41)$ and $107 \pm 11$ MFI $(n=3, P=0.16)$ with 10 or $25 \mu \mathrm{M}$ estramustine (see Figure 4). When $25 \mu \mathrm{M}$ estramustine was added to GLC4-MITO, the cellular mitoxantrone level increased to the same level as for GLC4 (see Figure 4). The BCRP1 (FTC), P-gp (PSC833) and MRPs (MK-571) inhibitors were added to GLC4MITO and GLC4 prior to addition of $3 \mu \mathrm{m}$ mitoxantrone, and the drug accumulation was measured by FACS analysis. The mitoxantrone accumulation expressed as MFI was set to 100 with addition of only $3 \mu \mathrm{M}$ mitoxantrone. The addition of the P-gp inhibitor PSC833 caused an increase in mitoxantrone accumulation to $113 \pm 19(n=3, P=0.17)$ in GLC4 and an increase to $114 \pm 20(n=3 P=0.19)$ in GLC4-MITO. When the inhibitor for BCRP1, FTC was added, a mitoxantrone increase was detected in GLC4 $(114 \pm 10(n=3 P=0.07))$ and GLC4-MITO $(128 \pm 8(n=3$, $P=0.02))$. However, there was no significant difference $(P=0.13)$ in mitoxantrone accumulation between the cell lines. The addition

Table 3 Transporter genes located in gained chromosomal areas when GLC4-MITO was compared with GLC4 using CGH

\begin{tabular}{|c|c|c|}
\hline Name (symbol) & Chromosomal location & References \\
\hline ABCB6 (ABCB6) & $2 q 33-q 36$ & Allikmets et al (1996) \\
\hline ABCB2 (TAPI) & $6 p 21.3$ & Bahram et al (|99|) \\
\hline ABCB3 (TAP2) & $6 p 21.3$ & Bahram et al (199|) \\
\hline ABCCIO (MRP7) & $6 p 21$ & Hopper et al (200I) \\
\hline$A B C F I(A B C 50)$ & $6 p 21.33$ & Richard et al (1998) \\
\hline $\mathrm{ABCA} 2(\mathrm{ABC} 2)$ & $9 q 34$ & Vulevic et al (200I) \\
\hline ABCC4 (MRP4) & $13 q 32$ & Kool et al (1997) \\
\hline
\end{tabular}

of the MRP inhibitor MK-571 caused an increase in mitoxantrone accumulation to $117 \pm 27$ in GLC4 $(n=3, P=0.09)$ and to $119 \pm 28$ $(n=3, P=0.22)$ in GLC4-MITO.

\section{DISCUSSION}

This study shows that with CGH it was possible to define an amplified chromosomal area, in which after a database search ABCA2 could be identified as a candidate gene involved in mitoxantrone resistance. In the mitoxantrone-resistant GLC4-MITO, mechanisms underlying the mitoxantrone accumulation defect were unknown (Withoff et al, 1996). Direct comparison with CGH of GLC4-MITO and its parental cell line GLC4 resulted in a simplified overview of numerical differences (see Table 2). These differences fitted in the complex karytotype obtained with cytogenetics. Although in both lines marker chromosomes were found, which made it difficult to identify chromosomal gains.

Mitoxantrone resistance in GLC4-MITO is at least partly due to the absence or low-level expression of topoisomerase II $\alpha$ and $\beta$ compared with its parental line (Withoff et al, 1996). The loss of $3 \mathrm{p}$ (containing the topoisomerase $\mathrm{II} \beta$ gene) and $17 \mathrm{q}$ (containing the topoisomerase II $\alpha$ gene) in GLC4-MITO detected with CGH is in accordance with this previously found reduction of topoisomerase activity (Withoff et al, 1996).

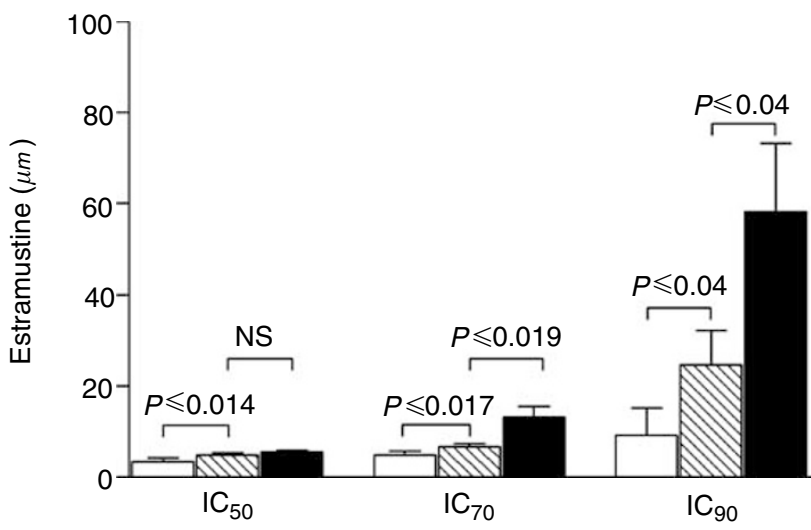

Figure 3 Representative cytotoxity profile of the estramustine sensitivities of GLC4-MITO (ם), GLC4-ADR ( $\square$ ) and GLC4 () measured with an MTA. Values represent the means of four experiments \pm s.d.

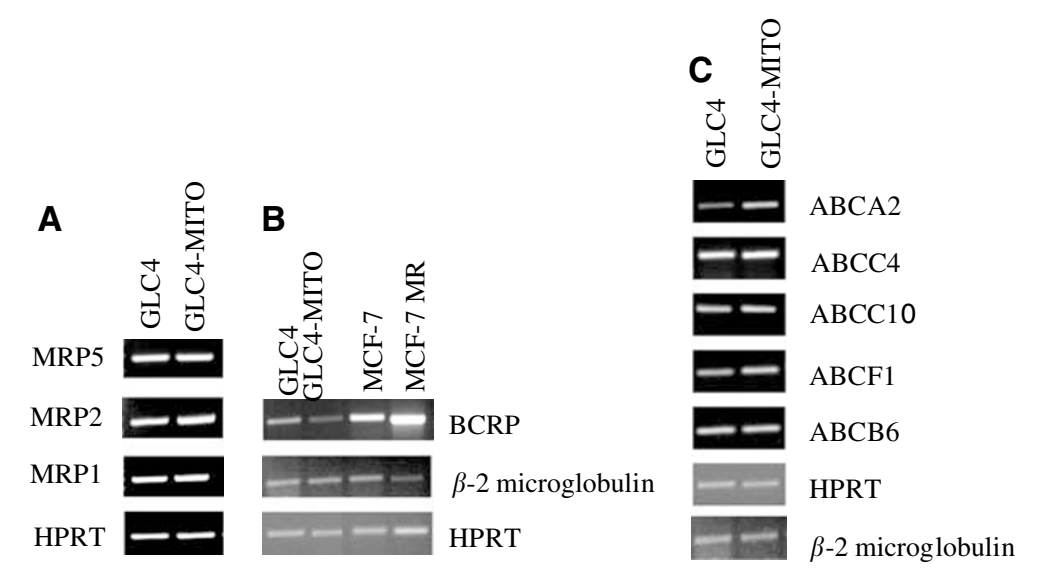

Figure 2 RT-PCR of selected efflux pump genes. (A, B): Expression of MRPI MRP2 MRP5 BCRP $\beta-2$ microglobulin and HRTP mRNA in the mitoxantrone-resistant cell line GLC4-MITO and sensitive cell line GLC4. (C): Expression of ABCB6 ABCFI ABCCIO ABCC4 ABCA2 $\beta$ 2-microglobulin and HRTP in the mitoxantrone-resistant cell line GLC4-MITO and its sensitive parent line GLC4. 


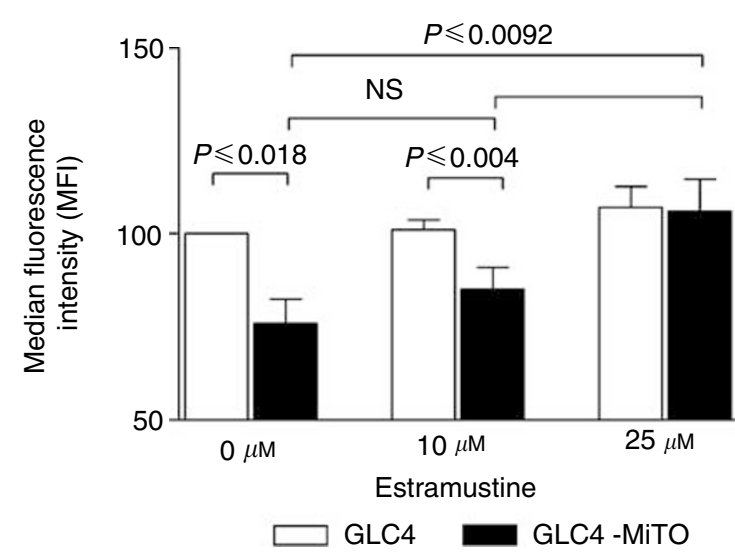

Figure 4 Effect of estramustine on mitoxantrone drug accumulation in GLC4 and GLC4-MITO. In total, 0, 10 and $25 \mu \mathrm{M}$ estramustine were added together with $3 \mu \mathrm{M}$ mitoxantrone to $1 \times 10^{6}$ GLC4 and GLC4-MITO cells. Median fluorescence intensity was measured indicating the relative amount of mitoxantrone accumulation. Values represent the median mitoxantrone fluorescence relative to GLC4 with $3 \mu \mathrm{M}$ mitoxantrone. Values represent the means of three experiments \pm s.d. No significant difference was observed in GLC4 with or without estramustine.

GLC4-MITO has a low level of doxorubicin crossresistance which might be completely due to lowered topoisomerase II levels (Withoff et al, 1996). This implies that an uncharacterised transporter protein capable of reducing mitoxantrone accumulation without a role in doxorubicin resistance is involved in mitoxantrone resistance in GLC4-MITO.

Mitoxantrone resistance has been contributed to overexpression of various $\mathrm{ABC}$ transporters. The BCRP1 half-transporter protein was found to be responsible for mitoxantrone resistance (Doyle et al, 1998; Miyake et al, 1999; Ross et al, 1999; Litman et al, 2000). Scheffer et al (2000) had already shown that there was no BCRP1 overexpression in GLC4-MITO using BXP-34 antibody. Comparative genomic hybridisation analysis in the present study revealed the loss of the 4q13-q28 region harbouring BCRP1 (4q21-22, Knutsen et al, 2000) in GLC4-MITO and a lower BCRP1 mRNA expression compared with GLC4 (Figure 2A). Thus, BCRP1 is not involved in mitoxantrone resistance in GLC4-MITO. ABCB2 and $\mathrm{ABCB} 3$ have been associated with mitoxantrone resistance in a gastric carcinoma cell line (Lage et al, 2001). Mitoxantrone resistance due to a reduced expression of topoisomerase II and an unknown efflux pump was observed in human (Hazlehurst et al, 1999; Diah et al, 2001) and mouse (Nielsen et al, 2000) cell lines. In the present study, several genomic regions that harbour candidate drug resistance genes in the GLC4-MITO were located. In these regions, seven transporter genes were identified (Müller M (2001) Transporters in the Liver and ATPbinding Casette (ABC)-Proteins October 2002. Internet communication, http://nutrigene.4t.com/ humanabc.htm). Reverse transcriptase-polymerase chain reaction for four transporter genes, ABCB6 (Allikmets et al, 1996), ABCF1 (Richard et al, 1998), ABCC4 (Kool et al, 1997) and ABCC10

\section{REFERENCES}

Allikmets R, Gerrard B, Hutchinson A, Dean M (1996) Characterization of the human ABC superfamily: isolation and mapping of 21 new genes using the expressed sequence tags database. Hum Mol Genet 5: $1649-1655$

Ambudkar SV, Dey S, Hrycyna CA, Ramachandra M, Pastan I, Gottesman MM (1999) Biochemical cellular and pharmacological aspects
(Hopper et al, 2001), and immunohistochemistry of two genes, ABCB2 and ABCB3 (Bahram et al, 1991), showed similar levels of mRNA and protein, respectively, in GLC4-MITO and GLC4.

However, the ABCA2 (Vulevic et al, 2001) gene located on 9q34 showed an increased mRNA expression in GLC4-MITO compared with GLC4. No causal link between ABCA2 and mitoxantrone resistance has been demonstrated. Gain of 9q34, including the ABCA2 transporter gene and overexpression of ABCA2 mRNA in an ovarian carcinoma cell line has been associated with enhanced efflux of estramustine (Laing et al, 1998). Transfection of ABCA2 in HEK293 cells resulted in a two-fold resistance to estramustine compared to normal HEK293 cells (Vulevic et al, 2001). ABCA2 has been suggested to play a role in the transport of steroids, lipids and related molecules (Vulevic et al, 2001; Zhou et al, 2001) and is expressed at high level in brain and neural tissue (The cancer genome anatomy project (2001): Sage Genie, Sage Anatomic Viewer, Digital Northern for ABCA2. Internet communication, http://cgap.nci.nih.gov/SAGE/AnatomicViewer). ABCA2 expression has been observed in tumour cell lines of different origin and intracellular localisation to the endosome/lysosome compartment was demonstrated (Vulevic et al, 2001). Lysosomes were capable of exocytosis in response to extracellular stimuli also in nonsecretory cells (Jaiswal et al, 2002). In the GLC4 and the GLC4-ADR cell lines, the transport of doxorubicin by secretory vesiscles with MRP1containing membranes was previously demonstrated (van Luyn et al, 1998). In GLC4-MITO (and GLC4), mitoxantrone extrusion could take place analogously by the lysosome exocytosis pathway.

Analysis of the cytotoxicity of estramustine on GLC4, GLC4MITO and GLC4-ADR showed a two-fold resistance in GLC4MITO (see Figure 3) comparable with the estramustine resistance found in an ABCA2-transfected cell line (Vulevic et al, 2001). Remarkably, the multidrug-resistant, MRP1-overexpressing GLC4ADR (Versantvoort et al, 1995; Withoff et al, 1996) was more sensitive to estramustine than the GLC4 control cell line (see Figure 3). In GLC4-MITO, addition of $25 \mu \mathrm{M}$ estramustine increased mitoxantrone accumulation to the level of GLC4 (see Figure 4), suggesting that estramustine is able to block mitoxantrone efflux in GLC4-MITO. This effect of estramustine is unlikely to be due to P-gp (Speicher et al, 1994; Smith et al, 1995) or MRP5 (Wielinga et al, 2003) of which estramustine has been shown to modulate the transport activity. In the present model, no P-gp overexpression and no (selective) effect of the P-gp blocker PSC833 on mitoxantrone accumulation were found. In GLC4MITO, no increased mRNA expression was found for MRP5 or one of the other multidrug-resistance related transporters tested. Mitoxantrone accumulation with specific inhibitors of P-gp, MRPs and BCRP1 revealed an a-selective and (except for FTC) not significant increase in mitoxantrone accumulation in GLC4 as well as in GLC4-MITO.

Our data provide genetic and biochemical support for the concept that ABCA2 expression is a plausible contributory factor to the multifactorial mitoxantrone-resistant phenotype, while for other transporters no apparent changes in the expression could be correlated with mitoxantrone accumulation or cytotoxicity. of the multidrug transporter. Annu Rev Pharmacol Toxicol 39: $361-398$

Bahram S, Arnold D, Bresnahan M, Strominger JL, Spies T (1991) Two putative subunits of a peptide pump encoded in the human major histocompatibility complex class II region. Proc Natl Acad Sci USA 88: $10094-10098$ 
Borst P, Evers R, Kool M, Wijnholds J (1999) The multidrug resistance protein family. Biochim Biophys Acta 1461: 347-357

Diah SK, Smitherman PK, Aldridge J, Volk EL, Schneider E, Townsend AJ, Morrow CS (2001) Resistance to mitoxantrone in multidrug-resistant MCF7 breast cancer cells: evaluation of mitoxantrone transport and the role of multidrug resistance protein family proteins. Cancer Res 61: $5461-5467$

Doyle LA, Yang W, Abruzzo LV, Krogmann T, Gao Y Rishi AK, Ross DD (1998) A multidrug resistance transporter from human MCF-7 breast cancer cells. Proc Natl Acad Sci USA 95: $15665-15670$

Hazlehurst LA, Foley NE, Gleason-Guzman MC, Hacker MP, Cress AE, Greenberger LW, De Jong MC, Dalton WS (1999) Multiple mechanisms confer drug resistance to mitoxantrone in the human 8226 myeloma cell line. Cancer Res 59: $1021-1028$

Hopper E, Belinsky MG, Zeng H, Tosolini A, Testa JR, Kruh GD (2001) Analysis of the structure and expression pattern of MRP7 (ABCC10) a new member of the MRP subfamily. Cancer Lett 162: 181-191

International Standing Committee on Human Cytogenetic Nomenclature (1995) In: Mittelman F (Ed). An International System for Human Cytogenetic Nomenclature. Basel, Switzerland: S. Karger AG

Jaiswal JK, Andrews NW, Simon SM (2002) Membrane proximal lysosomes are the major vesicles responsible for calcium-dependent exocytosis in nonsecretory cells. J Cell Biol 159: 625-635

Kallioniemi A, Kallioniemi OP, Sudar D, Rutovitz D, Gray JW, Waldman F, Pinkel D (1992) Comparative genomic hybridization for molecular cytogenetic analysis of solid tumors. Science 258: 818-821

Klein I, Sarkadi B, Varadi A (1999) An inventory of the human ABC proteins. Biochim Biophys Acta 1461: 237-262

Knutsen T, Rao VK, Ried T, Mickley L, Schneider E, Miyake K, Ghadimi BM, Padilla-Nash H, Pack S, Greenberger L, Cowan K, Dean M, Fojo T, Bates S (2000) Amplification of 4q21-q22 and the MXR gene in independently derived mitoxantrone-resistant cell lines. Genes Chromosomes Cancer 27: 110 - 116

Kool M, de Haas M, Scheffer GL, Scheper RJ, van Eijk MJ, Juijn JA, Baas F, Borst P (1997) Analysis of expression of cMOAT (MRP2) MRP3 MRP4 and MRP5 homologues of the multidrug resistance-associated protein gene (MRP1) in human cancer cell lines. Cancer Res 57: 3537-3547

Lage H, Perlitz C, Abele R, Tampé R, Dietel M, Schadendorf D, Sinha P (2001) Enhanced expression of human ABC transporter TAP is associated with cellular resistance to mitoxantrone. FEBS Lett 503: $179-184$

Laing NM, Belinsky MG, Kruh GD, Bell DW, Boyd JT, Barone L, Testa JR, Tew KD (1998) Amplification of the ATP-binding cassette 2 transporter gene is functionally linked with enhanced efflux of estramustine in ovarian carcinoma cells. Cancer Res 58: $1332-1337$

Litman T, Brangi M, Hudson E, Fetsch P, Abati A, Ross DD, Miyake K, Resau JH, Bates SE (2000) The multidrug-resistant phenotype associated with overexpression of the new ABC half-transporter MXR (ABCG2). J Cell Sci 113(Part 11): 2011-2021

Miyake K, Mickley L, Litman T, Zhan Z, Robey R, Cristensen B, Brangi M, Greenberger L, Dean M, Fojo T, Bates SE (1999) Molecular cloning of cDNAs which are highly overexpressed in mitoxantrone-resistant cells: demonstration of homology to $\mathrm{ABC}$ transport genes. Cancer Res 59: 8-13

Nielsen D, Eriksen J, Maare C, Litman T, Kjaersgaard E, Plesner T, Friche E, Skovsgaard T (2000) Characterisation of non-P-glycoprotein multidrugresistant Ehrlich ascites tumour cells selected for resistance to mitoxantrone. Biochem Pharmacol 60: $363-370$

Richard M, Drouin R, Beaulieu AD (1998) ABC50 a novel human ATPbinding cassette protein found in tumor necrosis factor-alpha-stimulated synoviocytes. Genomics 53: 137-145
Ross DD, Yang W, Abruzzo LV, Dalton WS, Schneider E, Lage H, Dietel M, Greenberger L, Cole SP, Doyle LA (1999) Atypical multidrug resistance: breast cancer resistance protein messenger RNA expression in mitoxantrone-selected cell lines. J Natl Cancer Inst 91: 429-433

Scheffer GL, Maliepaard M, Pijnenborg AC, van Gastelen MA, De Jong MC, Schroeijers AB, van der Kolk DM, Allen JD, Ross DD, van der Valk P, Dalton WS, Schellens JH, Scheper RJ. (2000) Breast cancer resistance protein is localized at the plasma membrane in mitoxantrone- and topotecan-resistant cell lines. Cancer Res 60: 2589-2593

Smith CD, Zilfou JT, Zhang X, Hudes GR, Tew KD (1995) Modulation of P-glycoprotein activity by estramustine is limited by binding to plasma proteins. Cancer 75: 2597-2604

Speicher LA, Barone LR, Chapman AE, Hudes GR, Laing N, Smith CD, Tew $\mathrm{KD}$ (1994) P-glycoprotein binding and modulation of the multidrugresistant phenotype by estramustine. J Natl Cancer Inst 86: 688-694

Timmer-Bosscha H, Hospers GA, Meijer C, Mulder NH, Muskiet FA, Martini IA, Uges DR, de Vries EG (1989) Influence of docosahexaenoic acid on cisplatin resistance in a human small cell lung carcinoma cell line. J Natl Cancer Inst 81: 1069-1075

Van der Kolk DM, Vellenga E, Scheffer GL, Muller M, Bates SE, Scheper RJ, de Vries EG (2002) Expression and activity of breast cancer resistance protein (BCRP) in de novo and relapsed acute myeloid leukemia. Blood 99: $3763-3770$

Van Luyn MJ, Muller M, Renes J, Meijer C, Scheper RJ, Nienhuis EF, Mulder NH, Jansen PL, de Vries EG (1998) Transport of glutathione conjugates into secretory vesicles is mediated by the multidrugresistance protein 1. Int J Cancer 76: 55-62

Versantvoort CH, Withoff S, Broxterman HJ, Kuiper CM, Scheper RJ, Mulder NH, de Vries EG (1995) Resistance-associated factors in human small-cell lung-carcinoma GLC4 sub-lines with increasing adriamycin resistance. Int J Cancer 61: 375-380

Volk EL, Rohde K, Rhee M, McGuire JJ, Doyle LA, Ross DD, Schneider E (2000) Methotrexate cross-resistance in a mitoxantrone-selected multidrug-resistant MCF7 breast cancer cell line is attributable to enhanced energy-dependent drug efflux. Cancer Res 60: 3514-3521

Vulevic B, Chen Z, Boyd JT, Davis Jr W, Walsh ES, Belinsky MG, Tew KD (2001) Cloning and characterization of human adenosine $5^{\prime}$-triphosphate-binding cassette sub-family A transporter 2 (ABCA2). Cancer Res 61: $3339-3347$

Wielinga PR, van der Heijden I, Reid G, Beijnen JH, Wijnholds J, Borst P (2003) Characterization of the MRP4- and MRP5-mediated transport of cyclic nucleotides from intact cells. J Biol Chem 278: $17664-17671$

Withoff S, de Vries EG, Keith WN, Nienhuis EF, van der Graaf WT, Uges DR, Mulder NH (1996) Differential expression of DNA topoisomerase II alpha and -beta in P-gp and MRP-negative VM26 mAMSA and mitoxantrone-resistant sublines of the human SCLC cell line GLC4. $\mathrm{Br}$ J Cancer 74: 1869-1876

Zhou C, Zhao L, Inagaki N, Guan J, Nakajo S, Hirabayashi T, Kikuyama S, Shioda S (2001) ATP-binding cassette transporter ABC2/ABCA2 in the rat brain: a novel mammalian lysosome-associated membrane protein and a specific marker for oligodendrocytes but not for myelin sheaths. I Neurosci 21: 849-857

Zijlstra JG, de Jong S, van de Grampel JC, de Vries EG, Mulder NH (1986) Different type of DNA damage caused by three aziridinyl substituted cyclophosphazenes in a human small cell lung carcinoma cell line. Cancer Res 46: 2726-2729

Zijlstra JG, de Vries EG, Mulder NH. 1987 Multifactorial drug resistance in an adriamycin-resistant human small cell lung carcinoma cell line. Cancer Res 47: $1780-1784$ 